\title{
Surgical resection of a cutaneous nodule in the left foot caused by mycobacteria
}

\section{Exérese cirúrgica de nódulo cutâneo no pé esquerdo causado por uma micobactéria}

Neiva Aparecida Grazziotin'; Itamar Luís Gonçalves²; Clara Grazziotin ${ }^{3}$

\begin{abstract}
Nontuberculous mycobacteria are etiologic agents of opportunistic human infections. Although they usually affect superficial tissues, infections in bones and joints have been described. The contamination is associated with increased environmental exposure. With appropriate therapy, the cases usually progress to complete recovery of the patient. This study reports the case of a patient who developed a cutaneous nodule in her left foot acquired when her skin was punctured by a fish. The anatomopathological examination revealed chronic central suppurative granulomatous dermo-hypodermal inflammation. Furthermore, the screening for resistant acid-fast bacilli was positive.
\end{abstract}

Key words: nontuberculous mycobacteria; mycobacteriosis; Mycobacterium sp.

\section{INTRODUCTION}

Mycobacteria include important pathogens such as Mycobacterium turbeculosis and M. leprae. Approximately 150 species are indigenous in the human environment ${ }^{(7,8)}$. Several species of nontuberculous mycobacterium have been reported in the states of Mato Grosso do Sul and Rio de Janeiro, Brazil ${ }^{(13,15)}$.

Mycobacterium marinum is among the pathogenic mycobacteria. It was initially described in 1926 during an investigation into infectious diseases in marine fish ${ }^{(2)}$. It has worldwide distribution and it is generally associated with cutaneous and bone-articular lesions ${ }^{(9)}$. Moreover, it is accountable for approximately 150 new cases in the United States annually ${ }^{(5)}$.

M. marinum is a natural pathogen in ectothermic animals, including amphibians and fish. In the latter they cause systemic granulomatous disease. Diseases caused by mycobacteria are among the most prevalent in fish ${ }^{(9,14)}$. It is particularly worrying the fact that bacteria involved in fish bacteriosis are able to infect humans ${ }^{(4)}$. Human infections caused by $M$. marinum produce nodular or ulcerated cutaneous lesions in upper or lower limb extremities $^{(12)}$

Delayed diagnosis is common and invasion of deeper structures such as synovium, bursae and bone occur in approximately a third of the reported cases ${ }^{(12)}$. A rare case of long bone osteomyelitis has been described in an immunosuppressed patient ${ }^{(16)}$. The contamination usually occurs through direct contact with fish or contaminated water, generally in the presence of a pre-existing wound or trauma $\mathrm{a}^{(1,4)}$

The present study describes the clinical progression of a patient who presented a wound caused by a fish. The microscopic exam of the affected area revealed the presence of resistant acidfast bacilli (RAFB).

\section{CASE REPORT}

In February 2007, 51 year-old female patient reported a superficial would in the left foot caused by a fish known as tilapia

First submission on 18/01/13; last submission on 19/03/13; accepted for publication on $03 / 05 / 13$; published on 20/06/13

1. Master's in Biological Sciences; professor in Mycology, Microbiology and Parasitology at Universidade Regional Integrada (URI) Erechim; biochemical pharmacist.

2. Graduate student in Pharmacy at URI Erechim; Scientific Initiation scholarship at URI Erechim.

3. Doctor specialist in Dermatology. 
The lesion was caused by trauma during fishing, which occurred in a city in the north region of Rio Grande do Sul, Brazil.

Fifteen days after the initial wound, the patient developed a small asymptomatic papule on the site. Two months afterwards, after trekking with sneakers, the lesion volume increased considerably, presenting a painful swollen erytematous nodule (Figure 1). Shortly after the onset of these symptoms, a traumatologist raised the diagnostic hypothesis of bursitis and prescribed applying ice to the affected region concomitantly with the use of a non-steroid anti-inflammatory drug orally. The clinical progression is illustrated in Figure 1.

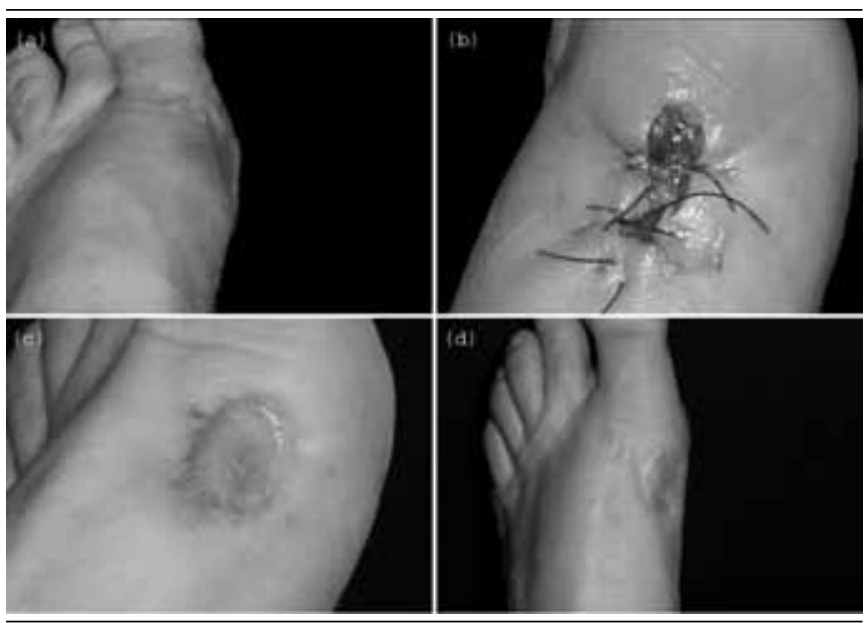

FIGURE 1 - Wound progression

(a) erytematous nodule observed three months after contact with etiologic agent; (b) aspect of the lesion after surgical excision; (c) aspect of the affected area approximately four months after surgical procedure; (d) affected foot five years after infection.

As the patient did not present any clinical improvement after prescribed treatment, microscopic, bacteriological and anatomopathologic exams were requested. Gram staining allowed to establish that there were no microorganisms in the site, though there were numerous leukocytes. Microscopic and bacteriological exams were negative. Moreover, there were no fungi in the direct exam and culture. The absence of microbiological findings led to RAFB screening through Ziehl-Neelsen staining, yielding positive results (Figure 2A and Figure 2B - Figure 2).

The patient received rifampicin $300 \mathrm{mg}$, which was administered every 12 hours during 3 days. Subsequently, the patient underwent total surgical excision (Figure 1B). The anatomopathologic results from the surgical specimen revealed chronic central suppurative granulomatous dermo-hypodermal inflammation (Figure 2C and Figure 2D). After surgical resection of the affected area, followed by epithelial grafts and hyperbaric treatment, the patient achieved full recovery with no relapses for five years and eight months (Figure 1D).
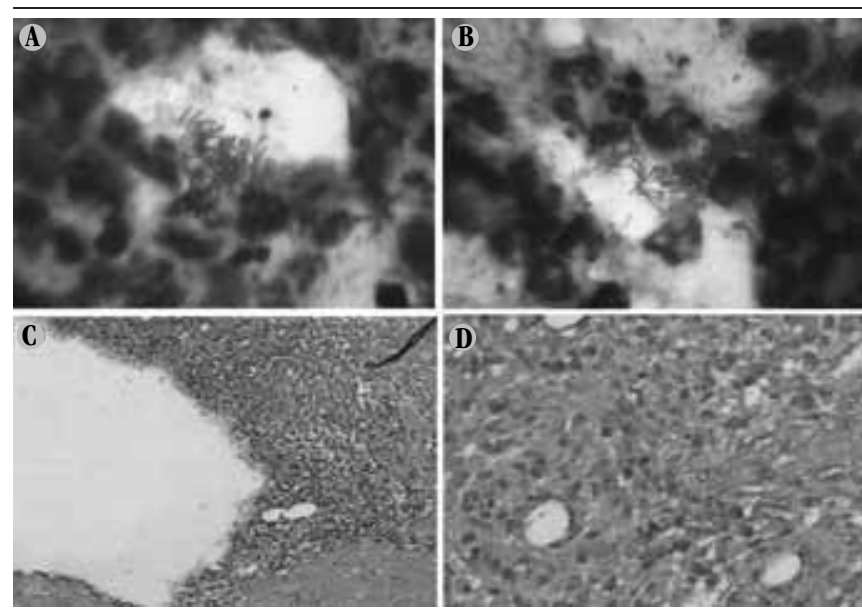

FIGURE 2 - RAFB screening and anatomopathologic exam

(a) and (b) resistant acid-fast bacilli visualized under optical microscopy at 1,000×. Samples were obtained from the lesion site and underwent Ziehl-Neelsen staining; (c) and (d) suppurative granuloma at $40 \times$ and $400 \times$, respectively.

RAFB: resistant acid-fast bacilli

\section{DISCUSSION}

Based on the patient's clinical history, Mycobacterium marinum was considered the most probable infectious agent, which is found in a wide variety of aquatic habitats worldwide. Accordingly, people who work with aquaculture or have aquariums have a higher risk of acquiring this infection.

Most patients with infections caused by $M$. marinum respond to antimicrobial treatment, though prolonged treatments are sometimes required for several months ${ }^{(1,6,17)}$. A review study assessed the clinical progression of 63 cases and concluded that the most commonly prescribed antibiotics were clarithromycin, tetracycline and rifampicin ${ }^{(3)}$. The use of clarithromycin is effective for most patients with cutaneous infections ${ }^{(10)}$. Nonetheless, refractory cases requiring several antibiotics and surgical procedures have been reported ${ }^{(18)}$ as well as cases in which the infection has led to death ${ }^{(11)}$.

The clinical progression of some cases reported by the literature is shown in the Table below.

In clinical practice, the diagnosis of cutaneous infection by M. marinum is established on the basis of the clinical history, lesion features, microbiological exam and molecular techniques. The contact with fish and aquariums plays a major role in the differential diagnosis, hence the need to investigate the patient's exposure to aquatic habitats. The better understanding of this infection enables an early approach, which reduces the potentially high risk of deeper tissue involvement. Therefore, in this specific case, the total surgical excision of a unique mycobacterial lesion was the treatment of choice. 
TABLE - Clinical progression of infections caused by M. marinum

\begin{tabular}{|c|c|c|c|c|c|c|}
\hline Reference & Age & Gender & Symptoms & Contamination & Therapy & Outcome \\
\hline 1 & 45 & M & $\begin{array}{l}\text { Draining sinuses in the } \\
\text { chest and arms }\end{array}$ & Swimming in water park & $\mathrm{R}, \mathrm{CL}$ and $\mathrm{AM}$ & $\begin{array}{l}\text { Improvement after a } \\
\text { three-month treatment }\end{array}$ \\
\hline 6 & 60 & M & $\begin{array}{l}\text { Epithelial lesion in the } \\
\text { right hand progressing to } \\
\text { nodules that reached the } \\
\text { forearm }\end{array}$ & $\begin{array}{l}\text { Cleaning aquarium } \\
\text { containing dead fish }\end{array}$ & $\mathrm{R}$ and $\mathrm{CL}$ & $\begin{array}{l}\text { Cured four months after } \\
\text { diagnosis }\end{array}$ \\
\hline 6 & 23 & M & $\begin{array}{l}\text { Nodule on the dorsal } \\
\text { surface of the right hand }\end{array}$ & $\begin{array}{c}\text { Skin lesion cleaning } \\
\text { aquarium }\end{array}$ & $\mathrm{R}, \mathrm{E}$ and $\mathrm{CL}$ & $\begin{array}{c}\text { Cured three months after } \\
\text { diagnosis }\end{array}$ \\
\hline 11 & 67 & M & $\begin{array}{l}\text { Painful subcutaneous } \\
\text { nodules on the right arm } \\
\text { and leg }\end{array}$ & $\begin{array}{l}\text { Aquarium with tropical } \\
\text { fish and turtle }\end{array}$ & $\mathrm{R}, \mathrm{E}, \mathrm{CL}$ and $\mathrm{CP}$ & Died after 111 days \\
\hline 17 & 16 & $\mathrm{~F}$ & $\begin{array}{l}\text { Slow healing nodular } \\
\text { lesion on the left leg }\end{array}$ & $\begin{array}{l}\text { Contact with barnacle } \\
\text { (marine crustacean) }\end{array}$ & $\mathrm{E}$ and $\mathrm{CL}$ & $\begin{array}{c}\text { Full recovery in four } \\
\text { months }\end{array}$ \\
\hline
\end{tabular}

M: male; F: female; R: rifampicin, E: ethambutol, CL: clarithromycin, CP: ciprofloxacin, AM: amikacin.

\section{RESUMO}

Micobactérias não tuberculosas são agentes causadores de infecções oportunistas no bomem. Embora, geralmente, afetem tecidos superficiais, infecções em ossos e articulações têm sido descritas. O contágio está associado ao aumento da exposição do bomem ao meio ambiente. Diante da terapêutica adequada, os casos normalmente evoluem com recuperação total do indivíduo. Este estudo descreve o caso clínico de um paciente que apresentou nódulo cutâneo no pé esquerdo após traumatismo com um peixe. 0 exame anatomopatológico revelou inflamação crônica granulomatosa centralmente supurativa dermo-bipodérmica e a pesquisa de bacilos álcool-ácido resistentes (BAAR) foi positiva.

Unitermos: micobactérias não turbeculosa; micobacteriose; Mycobacterium sp.

\section{REFERENCES}

1. AFZAL, A. et al. Mycobacterium marinum infection: a case report. JPAD, v. 19, p. 48-51, 2009.

2. ARONSON, J. D. Spontaneous tuberculosis in salt water fish.J Infect Dis, v. 39, p. 315-20, 1926.

3. AUBRY, A. et al. Sixty-three cases of Mycobacterium marinum infection: clinical features, treatment, and antibiotic susceptibility of causative isolates. Arch Intern Med, v. 162, n. 15, p. 1746-52, 2002.

4. BOWSER, P. R. Fish diseases: mycobacteriosis of fish. NRAC Publication, v. 202, p. 1-3, 2002.

5. DOBOS, K. M. et al. Emergence of a unique group of necrotizing mycobacterial diseases. Emerg Infect Dis, v. 5, n. 3, p. 367-78, 1999.

6. EL AMRANI, M. H. et al. Upper extremity Mycobacterium marinum infection. Orthop Traumatol Surg Res, v. 96, n. 6, p. 706-11, 2010.

7. EUZÉBY, J. P. List of bacterial names with standing in nomenclature: a folder available on the internet. Int J Syst Bacteriol, v. 47, n. 2, p. 590-2, 1997.
8. FALKINHAM, J. Nontuberculous mycobacteria in the environment. Clin Chest Med, v. 23, n. 3, p. 529-51, 2002.

9. FARD, S. M. H. et al. Mycobacterium marinum as a cause of skin chronic granulomatous in the hand. Casp J Intern Med, v. 2, n. 1, p. 198-200, 2011.

10. FENG, Y. et al. Outbreak of a cutaneous Mycobacterium marinum infection in Jiangsu Haian, China. Diagn Microbiol Infect Dis, v. 71, n. 3, p. 267-72, 2011.

11. IMAKADO, S.; KOJIMA, Y.; MORIMOTO. S. Disseminated Mycobacterium marinum infection in a patient with diabetic nephropathy. Diabetes Res Clin Pract, v. 83, n. 2, p. 35-6, 2009.

12. LAHEY, T. Invasive Mycobacterium marinum infections. Emerg Infect Dis, v. 9, n. 11, p. 1496-8, 2003.

13. MORAES, P. R. S. et al. Identification of non-tuberculous mycobacteria from the Central Public Health Laboratory from Mato Grosso do Sul and analysis of clinical relevance. Braz J Microbiol, v. 39, n. 2, p. 268-72, 2008 .

14. ROMANO, L. A.; SAMPAIO, L. A.; TESSER, M. B. Micobacteriose por Mycobacterium marinum em linguado Paralichthys orbignyanus e 
em barber goby Elacatinus figaro: diagnóstico histopatológico e imunohistoquímico. Pesq Vet Bras, v. 32, n. 3, p. 254-8, 2012.

15. SENNA, S. G. et al. Identificação de micobactérias não tuberculosas isoladas de sítios estéreis em pacientes em um hospital universitário na cidade do Rio de Janeiro. J Bras Pneumol, v. 37, n. 4, p. 521-6, 2011

16. SIVAN, M. et al. Ostéomyélite à Mycobacterium marinum d'un os long Mycobacterium marinum osteomyelitis of a long bone. Rev Rhum, v. 75, n. 9, p. 875-8, 2008.

17. TEBRUEGGE, M. et al. Mycobacterium marinum infection following kayaking injury. Int J Infect Dis, v. 14, n. 3, p. 305-6, 2010.

18. VAN SEYMORTIER, P.; VERELLEN, K.; DE JONGE, I. Mycobacterium marinum causing tenosynovitis. Fish tank finger. Acta Orthop Belg, v. 70 , n. 3, p. 279-82, 2004. 